\title{
Methods in Mapping Usability of Malaysia's Shopping Centre
}

\author{
Aida Affina Abdul Ghani ${ }^{1}$, Md. Yusof Hamid ${ }^{2}$, Siti Norsazlina Haron ${ }^{3}$, Nur Azfahani Ahmad ${ }^{4}$, Mariaty Bahari ${ }^{5}$ and Suriani \\ Ngah Abdul Wahab 6 \\ 1,2,3,4,5,6 Fakulti Senibina, Perancangan dan Ukur, UiTM Perak, Malaysia
}

\begin{abstract}
With more than 200 number of shopping centre in Klang Valley itself, we the consumer actually have vast of choices. Instead of the machineries varieties from the lower class product till the posh one, each of those shopping centres eventually offers the typical product same as others. Those shopping centers are competing with each other and in great endeavour to attract more consumers, to visit and spend. As for the visitor, the typical product and boring ambience seems similar in all malls, and is looking something beyond the standard. Something that promising quality embedded in shopping centre which evokes the various emotions of the user along their journey in malls. This quality is known as usability.. Usability; as defined generally is a global user's experience response with product, environment, service or facilities. It is an assessment in extracting the qualities of shopping centre design. In mapping it, there are a few synthesizing methods to implement it. Therefore, this paper purposely to review the method that been used in usability of Malaysia's shopping centre research with a few references on previous research done in usability assessment by predecessor's scholars. With the accentuation on three elements that anchoring what the usability is: effectiveness, efficient and satisfaction, it is hope that this overview can lead other researcher in portraying its relationship with the quality and 'user friendly' design of shopping centre.
\end{abstract}

Key Words: Walkthrough, Shopping Centre, Usability, Quality Design, Experience

\section{Introduction}

Malaysia is well known for its 'shopping paradise'. According to Malaysia Shopping Malls Association (PPK), 550 shopping centres in the country are serving 30.3 million populations. 218 out of this 550 number of shopping centres are in Kuala Lumpur, Selangor and Putarajaya itself.

As mentioned by Managing Director Of CBRE (CB Richard Ellis Malaysia), Mr. Allan Soo (2014), Malaysia has facing an oversupply number of retail space. This is worsened by another addition of 7.7 million sqft of retail space from 2012 till 2015 through the built of Paradigm Mall, Setia City Mall and NU Sentral Mall. This makes the overall of retail space almost 46 million square feet (sqft) in Klang Valley itself. Referring to the standard retail space sqft which is 5.5 sqft per person, Malaysia actually is higher compared to Bangkok where we stated 7.1 sqft per person, whereas Bangkok recorded 6.5 sqft vice versa.

These great numbers of shopping centers cause tight competition between them in attracting more visitors to visit and consume, thus escalate the profit through the increasing number of tenant. This is a bit alarming, where shopping center and its environment should

Corresponding author: aniffaadia@gmail.com appeal enough to attract the user; both visitors and tenants. However, the physical attraction is not enough to attract them; thus creating a subjective dimension of usability such as 'identity, familiarity, memorability and satisfaction' is vital.

\section{Built Environment Usability}

Users of the building normally behave contradict with what have been predicted by designers. As mentioned by Haron SN (2011), designers tend to longing for smart users with everything are in order, and better behaved [19] .Unfortunately, in reality; real building needs to fit in real behaviour of the users. There is gap of communication between the designers and the users $[1,29]$ that normally designers are not the subject in their environment design. Even Arthur and Groener (2005) said that in increasing the user's satisfaction, it is essential to cater the needs of the user at early design stage accurately. Therefore, a quality designed building is totally depends on the input from the user.

Building that has quality of use is a usable building. As specified by International Council For Research and Innovation In Building and Construction (CIB) Task Group 51, a quality of use building is a building that efficiently in use (resources, productivity, effectiveness, 
rationality), expected effect in use (value increasement) and offering the wanted quality in use (satisfaction). From that statement, it can draw that this is a part of usability traits. Usability is related to the ease of use or user friendly. According to ISO (1998), usability defined as '...effectiveness-ability, efficiency and satisfaction with which a specified of users can achieve a specified set of tasks in a particular environment'. To be detail, this illustrates a product's usability as:

- Effectiveness - whether users can achieve what they want to do with the product

- Efficient -how long it takes them to achieve it

- Satisfaction - their feelings and attitude toward the product

This jargon actually came to the fore in 1950s where it was widely used in Human Computer Interaction [22, 24]. Latter, it has been used in product design, web design and information technology. Most gigantic companies such as Apple's PowerBook, Johnson and Johnson are success in producing their product by using usability as its design strategy. However, there is escalating interest in the application of usability in built environment practices nowadays [2, 21, 33]. The endeavour can be visibly seen from the establishment of International Council For Research and Innovation In Building and Construction (CIB) Task Group 51"Usability of Buildings 2005", Workshop W111"Usability Of Workplaces 2- 2008" and "Usability Of Workplace 3" in promoting better understanding on user experience and usability concept.

Basically, usability in built environment focuses on user perception on the easiness and efficient usage of facilities- the workplace [2]. It can be a tool to evaluate building which requires the total participation of user and their experience are incorporate in it. In evaluating the usability of the building, the relation of the building and people/ organisation is the main focus of subject. As mentioned by Blakstad (2008), this user often interacts with building by using all their senses, social and cultural unconsciously.

Contradicts with POE (Post Occupancy Evaluation) by Preiser et. al (1988) this usability is based on user perspective. Essentially, all previous methods in evaluating the building performance merely on the physical of the building (functionality); and none of it concentrates on the fitness of its design purpose with the application by the user. Hansen et.al (2010) illustrates the difference on functionality and usability clearly. Functionality of a building is more on how it works according to specification, quite critical but it is not significant from the aspect of successful of use. However, testing usability is related on how the building suits the organisation's goal, and user's experience and satisfaction.

As a platform of various activities, shopping centre is crucial in eliciting its usability. With frequent changes of user environment and format, a shopping centre should be usable enough for a workplace, spending place and an entertainment place as well. The shopping centre usability framework is gauged from three essential elements (Fig 1.0) as described by Alho
(2008) which is based on Rothe (2006) and Mantyla (2001)'s magnum opus. The 3 elements are : Shopping Centre (Environment), User and Usability Attributes (Situation, Goals which the products been used). In order to evaluate the usability of shopping centre, Alho et.al, stressed on which perspective that we are assessed from; the visitor or tenant. This is because usability is a matter of viewpoint, which the different user will tell the different definition, knowledge of usability. This is aligned with Sinkkonen et.al (2002) that described users are vary according to background, culture, habits , knowledge and know how.

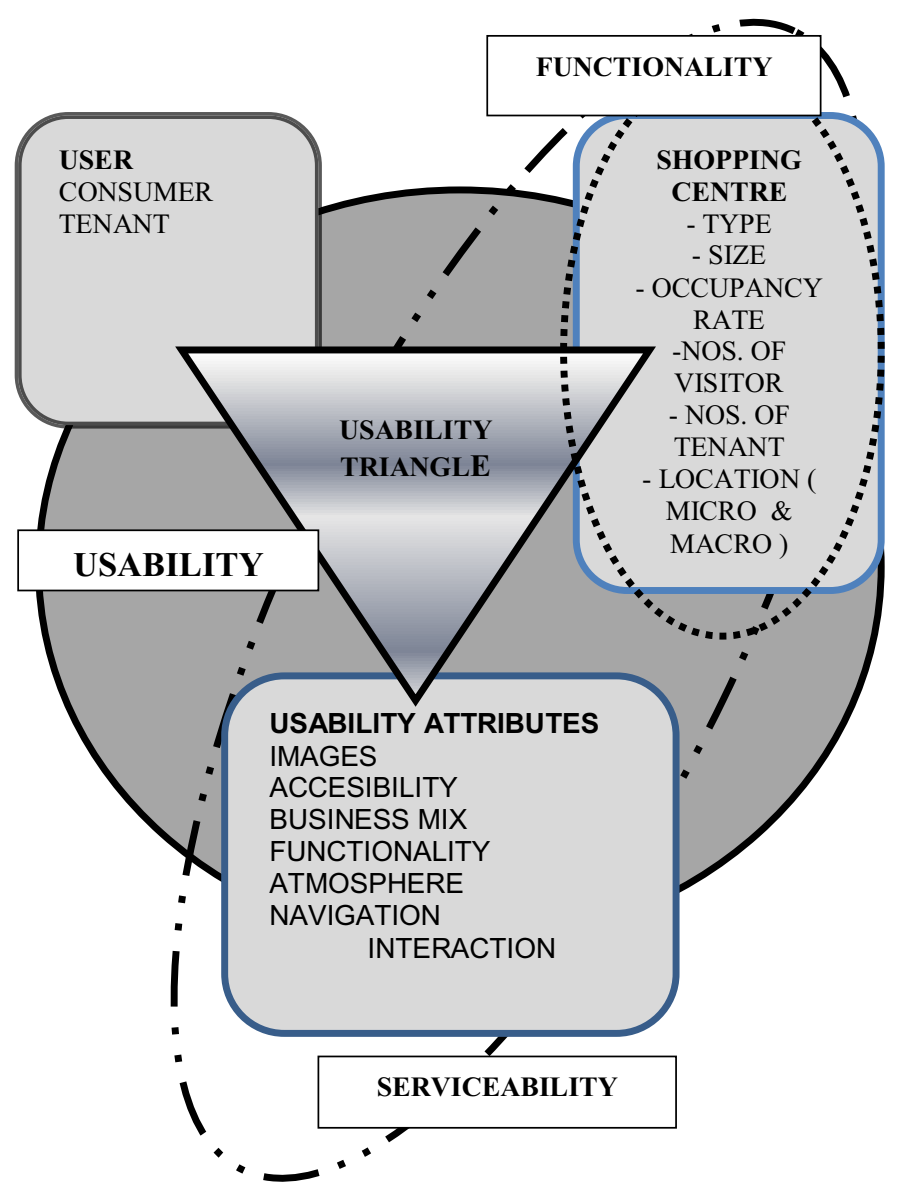

Fig 1.0 : Usability Shopping Centre Framework (Alho (2008), Rothe (2006)

\section{Usability Walkthrough Assessment}

Walkthrough is a common method in evaluating usability of a building. There are two types of walkthrough inspections which are cognitive walkthrough and pluralistic walkthrough. Cognitive walkthrough is based on task orientation whereas Pluralistic Walkthrough is a combination of usability inspection and testing.

Basically, most usability walkthrough assessment method is done based on heuristic evaluation method $[1,11,15$, and 26]. This method is easy to execute due to its ease of implementation, cheap and fast. By using 
$4-5$ evaluators which normally expertise in technical, the design system in the environment is audited based on the set of usability principles [27]. Nevertheless, these 10 usability principles were too flat and have been improvised by combined with several usability evaluation methods such as hierarchical heuristic structure, empirical testing at different phases along the development process and Systematic Usability Evaluation (SUE) [3, 11 and 23].

The latest walkthrough method; USEtool which promoted by Blakstad et.al (2010) ; had been used in extracting usability of Malaysia's hospital by Haron SN in 2014. USEtool is seen as a holistic usability method which blends the importance role of organisation, the user and the physical of an asset in one assessment. In USEtool, Blakstad et.al (2010) provide in depth knowledge on usability through the user experiences of existing buildings. This input practically can be used by Facilities Manager of an organisation as a reference in choosing new premise or planning a new building.

In addition, there are several methods that have been used by previous scholars in evaluating the usability of building shown in Table 1. Most of the usability scholars chose more than one method in executing usability mapping in their research.

Table 1 : Method Of Usability Mapping

\begin{tabular}{|c|c|}
\hline $\begin{array}{l}\text { RESEARCH METHOD AND } \\
\text { TECHNIQUES }\end{array}$ & OUTCOMES \\
\hline On Site Observation & $\begin{array}{l}\text { Behavior vs. } \\
\text { design }\end{array}$ \\
\hline $\begin{array}{l}\text { Observing physical traces: } \\
\text { Systematically looking at physical } \\
\text { surrounding and } \\
\text { reflection of previous activity. } \\
\text { Focus on functional issues, } \\
\text { Adaptations for use/ Public massage/ } \\
\text { Display of self/ } \\
\text { Product of use / User patterns [ }\end{array}$ & $\begin{array}{l}\text { Functional } \\
\text { design } \\
\text { criteria } \\
\text {.Behavior } \\
\text { and appearance } \\
\text { map design- } \\
\text { spatial } \\
\text { information \& } \\
\text { Efficient } \\
\text { Operation }\end{array}$ \\
\hline $\begin{array}{l}\text { Observation -Environmental } \\
\text { behavior activities: } \\
\text { People activities \& spatial- } \\
\text { relationship. } \\
\text { Systematically watching people use } \\
\text { their } \\
\text { environment - context/setting/ pattern } \\
\text { /culture/ } \\
\text { expected uses, new uses, misuses\& } \\
\text { opportunities }\end{array}$ & $\begin{array}{l}\text { Support } \\
\text { humans } \\
\text { without } \\
\text { disturbing } \\
\text { their activities. } \\
\text { Recognized } \\
\text { needs } \\
\text { Full } \\
\text { Participants. }\end{array}$ \\
\hline $\begin{array}{l}\text { Walk-through observation and } \\
\text { Cognitive walk through } \\
\text { User journey experience -User } \\
\text { experience feedback } \\
\text { surrounding design. Analyses of the } \\
\text { space and } \\
\text { movements "tour" of the building }\end{array}$ & $\begin{array}{l}\text { Assessing } \\
\text { different } \\
\text { qualities } \\
\text { functions } \\
\text { and audit of - } \\
\text { environmen }\end{array}$ \\
\hline Survey & Users \\
\hline
\end{tabular}

\begin{tabular}{|c|c|}
\hline & $\begin{array}{l}\text { perspective \& } \\
\text { feedback }\end{array}$ \\
\hline $\begin{array}{l}\text { Interviews useful as follows-up to } \\
\text { certain } \\
\text { Getting the story behind a participant's } \\
\text { experiences. } \\
\text { Obtain in-depth information around } \\
\text { the topic. } \\
\text { Interviews useful as follows-up to } \\
\text { certain } \\
\text { questionnaire and support behaviors } \\
\text { reaction }\end{array}$ & $\begin{array}{l}\text { Knowing } \\
\text { related } \\
\text { issue \& } \\
\text { exploration } \\
\text { related } \\
\text { evidence } \\
\text { support survey }\end{array}$ \\
\hline $\begin{array}{l}\text { Investigate consumer's psychological } \\
\text { feeling when interacting with product }\end{array}$ & $\begin{array}{l}\text { Product that } \\
\text { matches with } \\
\text { the users's } \\
\text { definition }\end{array}$ \\
\hline $\begin{array}{l}\text { RESEARCH METHOD AND } \\
\text { TECHNIQUES }\end{array}$ & OUTCOMES \\
\hline $\begin{array}{l}\text { Questionnaire } \\
\text { Using Structured question }\end{array}$ & $\begin{array}{l}\text { Needs and } \\
\text { demand }\end{array}$ \\
\hline \multicolumn{2}{|l|}{ Others methods } \\
\hline $\begin{array}{l}\text { Story telling and personas: } \\
\text { Expression of what user's perspective } \\
\text { and users } \\
\text { experience }\end{array}$ & $\begin{array}{l}\text { Personal needs } \\
\text { Attach to } \\
\text { product } \\
\text { design. }\end{array}$ \\
\hline $\begin{array}{l}\text { workshops : } \\
\text { Participatory Getting an idea and } \\
\text { sharing knowledge } \\
\text { about the conflict they experienced, } \\
\text { engaging with } \\
\text { the group to form strategies. }\end{array}$ & $\begin{array}{l}\text { Aims and } \\
\text { objectives as } \\
\text { well } \\
\text { as discussing } \\
\text { future } \\
\text { work }\end{array}$ \\
\hline $\begin{array}{l}\text { Focus group: } \\
\text { Perspective from the specific group } \\
\text { and organized } \\
\text { discussion with a selected group of } \\
\text { individual } \\
\text { discuss and comment on, from } \\
\text { personal experience } \\
\& \text { expectation }\end{array}$ & $\begin{array}{l}\text { It limited to the } \\
\text { ideas and } \\
\text { issues at } \\
\text { the time of the } \\
\text { session. }\end{array}$ \\
\hline $\begin{array}{l}\text { Document analysis: } \\
\text { To know current design practice and } \\
\text { understand a } \\
\text { present situation. } \\
\text { Purpose to support finding }\end{array}$ & $\begin{array}{l}\text { Gap of practice } \\
\text { Lacking of data } \\
\text { or } \\
\text { sources. } \\
\text { Lacking of } \\
\text { implementation }\end{array}$ \\
\hline $\begin{array}{l}\text { Mapping: } \\
\text { Using structured group interviews } \\
\text { Systematic approach for organizing } \\
\text { information } \\
\text { more effectively. Improve operating } \\
\text { efficiency \& } \\
\text { performance }\end{array}$ & $\begin{array}{l}\text { Creating model } \\
\text { and } \\
\text { standards. } \\
\text { Establishing } \\
\text { new } \\
\text { efficient } \\
\text { systems } \\
\text { and processes }\end{array}$ \\
\hline $\begin{array}{l}\text { USE tool: a 5-stage process } \\
\text { 1. Define the evaluation - for what } \\
\text { 2. Mapping usability-what } \\
\text { 3. Walk through-where \&who }\end{array}$ & $\begin{array}{l}\text { Assessment } \\
\text { method } \\
\text { flow in } \\
\text { gathering \& }\end{array}$ \\
\hline
\end{tabular}




\section{Workshop organization-why}

5. Action plan \& report-who

analysis data-
improving or
future
solution

(Source : Blakstad et.al (2008), Becker et.al (2007), Kazanasman et.al, (2006), Voordt (2009), Teck (2006), Uchira et.al, (2009), Haron et.al (2013), Alexander (2006), Nenonen and Rasila (2009), Nagamachi and Lokman (2010)

\section{Malaysia's Shopping Centre Usability Assessment}

Table 2 : Method Of Malaysia's Shopping Centre Usability

\begin{tabular}{|c|c|c|c|}
\hline $\begin{array}{c}\text { RESEARCH } \\
\text { METHOD } \\
\text { AND } \\
\text { TECHNIQUE } \\
S\end{array}$ & OUTCOMES & USING & THROUGH \\
\hline $\begin{array}{l}\text { Document } \\
\text { analysis: } \\
\text { To elicit the } \\
\text { usability } \\
\text { attributions } \\
\text { theoretically } \\
\text { from current } \\
\text { trends } \\
\text { Purpose to } \\
\text { support } \\
\text { finding }\end{array}$ & $\begin{array}{l}\text { Gap of } \\
\text { practice } \\
\text { Usability of } \\
\text { Shopping } \\
\text { Centre } \\
\text { Attribution, } \\
\text { Thematic } \\
\text { Analysis }\end{array}$ & \multirow{3}{*}{$\begin{array}{l}\text { USE tool: } \\
\text { a 5-stage } \\
\text { process } \\
\text { 1. Define } \\
\text { the } \\
\text { evaluation } \\
\text { - for what } \\
\text { 2. } \\
\text { Mapping } \\
\text { usability- } \\
\text { what } \\
\text { 3. Walk } \\
\text { through- } \\
\text { where } \\
\text { \&who } \\
\text { 4. } \\
\text { Workshop } \\
\text { organizati } \\
\text { on-why } \\
\text { 5. Action } \\
\text { plan \& } \\
\text { report- } \\
\text { who }\end{array}$} & \multirow{3}{*}{$\begin{array}{l}\text { Focus } \\
\text { Group: } \\
\text { Perspective } \\
\text { from the } \\
\text { specific } \\
\text { group and } \\
\text { organised } \\
\text { discussion } \\
\text { along the } \\
\text { walkthroug } \\
\text { h, voicing } \\
\text { out loud } \\
\text { (VOL) the } \\
\text { experience } \\
\text { and the } \\
\text { expectation } \\
: \text { 1. Visitor } \\
\text { Group } 2 . \\
\text { Various } \\
\text { Ages } 3 \text {. } \\
\text { Various } \\
\text { Gender }\end{array}$} \\
\hline $\begin{array}{l}\text { On Site } \\
\text { Observation }\end{array}$ & $\begin{array}{c}\text { Behavior } \\
\text { vs. design }\end{array}$ & & \\
\hline $\begin{array}{l}\text { Observing } \\
\text { physical } \\
\text { traces: } \\
\text { Physical } \\
\text { surrounding } \\
\text { observant ; } \\
\text { scrutinizing } \\
\text { the purpose o } \\
\text { its design and } \\
\text { how does it } \\
\text { functioning; } \\
\text { (Center For } \\
\text { The Universa } \\
\text { Design, 1997 } \\
\text { Observation } \\
\text { - } \\
\text { Environmen } \\
\text { al behavior } \\
\text { activities: } \\
\text { What people } \\
\text { do during } \\
\text { their visit on } \\
\text { shopping } \\
\text { centre; } \\
\text { interacting } \\
\text { with physical }\end{array}$ & $\begin{array}{l}\text { Recognised } \\
\text { their pattern } \\
\text { of use } \\
\text { without } \\
\text { disturbing } \\
\text { the activities }\end{array}$ & & \\
\hline
\end{tabular}

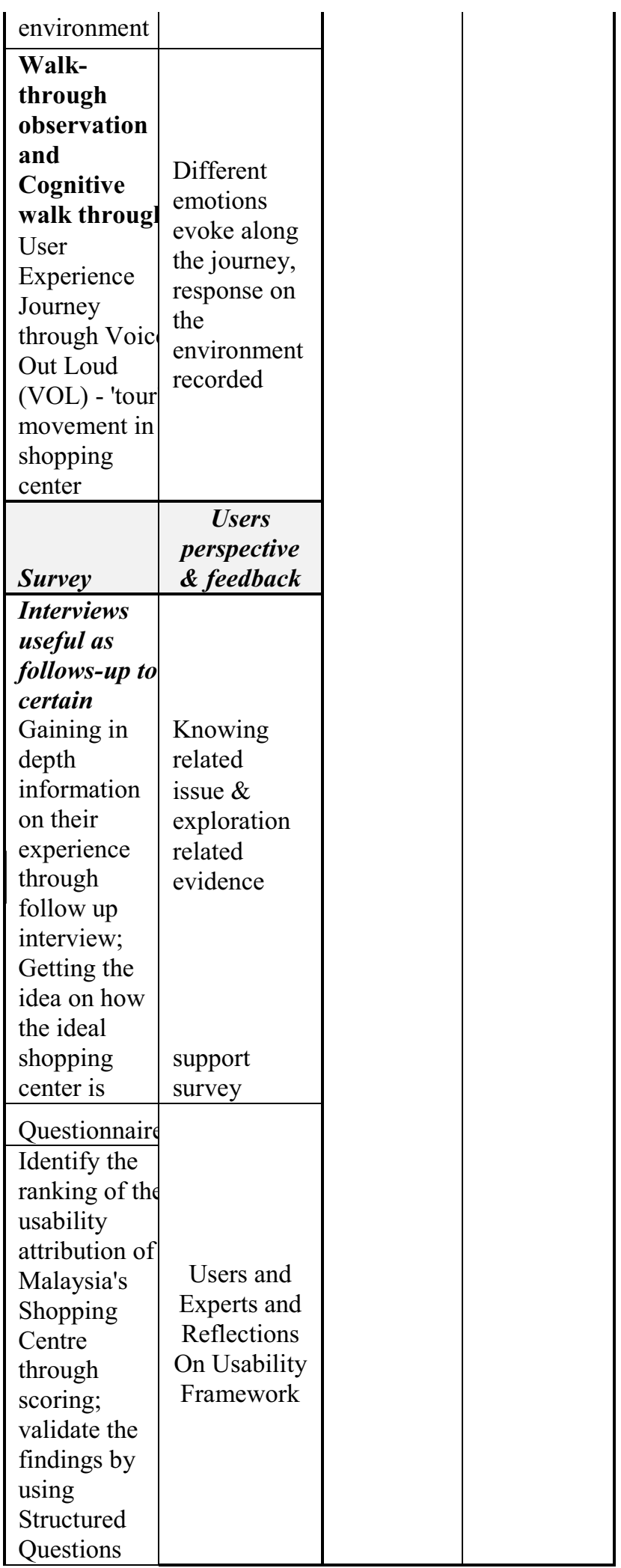

As a crucial place with various user environments, eliciting its usability is hardly to find in Europe's current research of shopping centre; except for a few scholars [3, 35]. The same goes to our Malaysia's context where there are a lot of researches done on the attractiveness of shopping centre from the marketing point of view. The scholars were concentrating more on the retails strategy such as promotion, merchandising, brands, product quality and entertainment [40, 41 and 
42]. Therefore, this usability evaluation seems to fill the loop on the quality design of Malaysia's shopping centre.

Generally, this research is dominated by qualitative type field. Moreover, to test the usability, it needs variety of tools; methods aspects because it depends on the objectives, purpose, and focus [26 and 34].

An initiative to understand thoroughly the phenomenon of usability, the research carries phenomenological philosophy which lies in interpretivism doctrine. Moreover, it is based on logical reasoning with emphasising the exploration and investigation of nature. This phenomenological research is purposely to understand the perception and the perspective of the user (visitor) of Malaysia's shopping centre on its usability. Furthermore, this research needs to be triangulated by executing several methods in the same phenomenon [13] in order to strengthen 'a confluence of evidence that breeds credibility' [14].

Basically, as referring to the Table 2 above, the method applied in this research is extracted from Usability Evaluation Method or known as 'USEtool' by Blakstad et.al (2011) and is based on Usability Shopping Centre framework introduced by Alho, et.al (2010). The 'USEtool' is used as a guideline in preparing the method outline for this research as it enhances the role of organization as epitome in the usability of shopping centre. Moreover, this systematic approach has been used in mapping the usability of building of an organization in previous studies. With a systematic approach of 5 stages mapping the phenomenon and reflecting the objectives of study, it helps in collecting, analysing, reporting and presenting data of research.

\section{Stage 1 - Define the Evaluation (What)}

The flow of this research method started with defining the purpose of usability evaluation- Stage I. Through Document Analysis, the aim is to extract usability criteria of shopping centre theoretically. As agreed by Corbin and Strauss (2008) et.al, the data from the documents are analysed and examined, thus interpreted to gain depth understanding and establish empirical knowledge. A thorough extensive literature review made based on theories on attractiveness and usability of shopping centre, both from marketing, business doctrine and built environment doctrine thus synthesized in order to create the attributes and theme for thematic analysis purpose. At this stage, a theoretical framework on Usability of Shopping Centre is set up.

\section{Stage 2 - Mapping Usability (What)}

The mapping process is guided by theoretical framework on Usability of Shopping Centre. At this stage, all relevant data are gathered including the background and the key figures of the shopping centre. In addition, the designated user team is identified before implementing the walkthrough process. Principally, the physical surrounding is firstly scrutinised as direct observation in seeking the virtual traces on how that shopping centres functioning and the user interacting with the physical environment at mall.

Stage 3 - Walkthrough (Where and Who)

The 'journey' started where the user experience are taken into consideration. Each of their emotion that evoked along the journey is tape recorded as the user implementing the 'Voice Out Loud' walkthrough; expressing their action and thought every time it came across into their mind. As Chebat et.al, (2005) mentioned, the focus is not on the total observation, but the thought that counts. The focus group conducted are requested to find a predetermined store in the shopping centre. Along the journey, the group then are instructed to record on what they see and the feel until they reach their destination.

\section{Stage 4- Validation Process (Why)}

At this stage, the findings of the research will be tabled consecutively to identify the linkage between the issues. Then, the results will be validated and triangulated within the main case study results and other multiple methods in order to support the main results. According to Patton (1990), triangulation avoids the research's bias or accusation on simplifying the findings as single source or method. This agreed by Bowen (2009) which states that researcher can avoid being potentially bias through various data sets by different methods collection. In this task, the respondents of two groups which consist of users and experts are given a set of questionnaire that uses five Likert scales (from strongly disagree to strongly agreed).

\section{Stage 5 - Final Report (Reporting)}

By triangulation the data gained through the main case studies, expert's review and the user's perception on the usability of Malaysia's shopping centre, a final report is produced. This report is tending for the purpose of:

- Improvisation of user experience in usability of shopping centre

- Enhance the usability of shopping centre

- Reference for the facilities manager and top management in enhancing the 'user friendly' design at early stage for future project

\section{Conclusion}

Summarily, this overview of method used in mapping the usability of shopping centre is devoted to facilitate the researcher on the variance of means. The choice of method selection must be suitable with the usability phenomenon and its philosophy. With the accentuation on three elements that anchoring what the usability is: effectiveness, efficient and satisfaction, it is hoped that this overview can lead other researcher in portraying its 
relationship with the quality and 'user friendly' design of mall.

\section{References}

1. Afacan, Y., \& Erbug, C. (2009). An interdisciplinary heuristic evaluation method for universal building design. AE, 40(4), 731-744. doi:10.1016/j.apergo.2008.07.002

2. Alexander, K. (2006). The application of usability concepts in the built environment. JFM, 4(4), 262270. doi:10.1108/14725960610702947

3. Alho, J., \& Nenonen, S. (2008). Usability of shopping centres: Components of a usability rating tool. W111 usability of workplaces phase 2. CIB Reports 316. Rotterdam: CIB.

4. Andre, S.T., Hartson, H.R., Belz, M.S., Mccreary, F.A., 2001. The user action frame- work: a reliable foundation for usability engineering support tools. Interna- tional Journal of Human-Computer Studies 54 (1), 107-136

5. Arthur, J.D., Gro "ner, M.K., 2005. An operational model for structuring the require- ments generation process. Requirements Engineering 10 (1), 45-62.

6. Bowen, G. A. (2009). Document Analysis as a Qualitative Research Method. Qualitative Research Journal (RMIT Training Pty Ltd Trading as RMIT Publishing), 9, 27-40. doi:10.3316/qrj0902027

7. Chebat, J., Ge, C., \& Therrien, K. (2005). Lost in a mall, the effects of gender, familiarity with the shopping mall and the shopping values on shoppers , way finding processes, 58, 1590-1598. doi:10.1016/j.jbusres.2004.02.006

8. C.K.K.Teck, "A user-centred approach to effective wayfinding map design:Integrating theory, practice and user participation',Faculty of Built Environment, Art and Design .Curtin University of Technology. Disertation Doctor of Philosophy,2006

9. Clarkson, J., Coleman, R., Hosking, I., Waller, S., 2007. Inclusive Design Toolkit. Cambridge Engineering Design Centre Press, Cambridge. Retrieved from: www. inclusivedesigntoolkit.com/betterdesign (1.10.07).

10. Corbin, J. \& Strauss, A. (2008). Basics of qualitative research: Techniques and procedures for developing grounded theory (3rd ed.). Thousand Oaks, CA: Sage.

11. Darses, F., Wolff, M., 2006. How do designers represent to themselves the users' needs? Applied Ergonomics 37 (6), 757-764.

12. De Angeli, A., Matera, M., Costabile, M.F., Garzotto, F., Paolini, P., 2003. On the advantages of a systematic inspection for evaluating hypermedia usability. International Journal of Human-Computer Interaction 15 (3), 315-335.

13. Denzin, N. K. (1970). The research act: A theoretical introduction to sociological methods. New York: Aldine

14. Eisner, E. W. (1991). The enlightened eye: Qualitative inquiry and the enhancement of educational practice. Toronto: Collier Macmillan Canada.

15. F. Becker, and K. S. Parsons,"Hospital facilities and the role of evidence-based design". Journal of Facilities Management 5(4),pp.263-274,2007.

16. Fu, L., Salvendy, G., Turley, L., 2002. Effectiveness of user testing and heuristic evaluation as a function of performance classification. Behaviour and Infor- mation Technology 21 (2), 137-143.

17. Hansen, Geir K; Blakstad, Siri H; Knudsen, W. (2011). USEtool Evaluating Usability: Methods Handbook. Ntnu.

18. Harding, J.A., Popplewell, K., Fung, R.Y.K., Omar, A.R., 2001. An intelligent informa- tion framework relating customer requirements and product characteristics. Computers in Industry 44 (1), 51-65.

19. Harrison, J., Parker, K., 2005. Designing for real people's lifelong needs. In: Proceedings of UIA Region IV Work Programme 'Architecture for All' UIA/ ARCASIAWorkshop. 3-10 Istanbul, Turkey, pp. 15-24.

20. Haron, S. N., \& Hamid, M. Y. (2011). Patient perspective: The " Usability evaluation " approaches as assessment for quality of outpatient spatial design . Ipcbee, 8, 4-8.

21. Nagamachi, $M$ and Lokman, A., 2010. Kansei Engineering : A B Binner Perspective.UniversityPublication Centre (UPENA),UiTM 2010

22. J. A. Granath and J. Gilleard, "Usability in the Workplace:Case study of Pamela Youde Eastern Hospital Hong Kong”, Usability of Workplaces 2, CIB and EuroFM. CIB reports 316.Rotterdam,2008

23. J. Gulliksen, "Usability Professionals-Current Practices And Future Development." Interacting With Computers 18,pp 568-600,2006.

24. Kantner, L., Rosenbaum, S., 1997. Usability studies of www sites: heuristic evalua- tion vs. laboratory testing. Reprint of paper from SIGDOC 97 Proceedings (Salt Lake City, UT). Published by Association for Computing Machinery, Inc. Retrieved from: http://www.teced.com/PDFs/sigdoc97.pdf [01.12.05]

25. M. Fenker, "Towards A Theoretical Framework For Usability Of Buildings". Usability of Workplaces 2, CIB and EuroFM. CIB reports 316.Rotterdam,2008.

26. M. Jensø and T. Haugen, "Usability Of Hospital Buildings :Is patient focus leading to usability in hospital buildings?", Usability OfWorkplaces:Case study: Nord-Trøndelag University College Nylåna, Røstad. CIB Task Group 51,2005.

27. Nielsen, J., Molich, R., 1990. Heuristic evaluation of user interfaces. SIGCHI Bulletin April (Special Issue), 249-256.

28. Nielsen, J., 1992. Finding usability problems through heuristic evaluation. In: Proceedings of CHI '92, California, USA, pp. 373-380 
29. Niemi R., Nenonen S. \& Junnonen J-M. (2013), Investigating the competencies for Serviceability of Urban areas, paper presented at the CIB World Building Congress 2013, Brisbane. 7.5.2013.

30. Patton, M. Q. (2002). Qualitative research and evaluation methods. Thousand Oaks, CA: Sage

31. Preiser, W., 2003. Inclusiveness through universal design feedback and evaluation. Education and evaluation - resources and methods at student level. In: Proceedings of Include 2003. Royal College of Art, London.

32. Rapley, T. (2007). Doing conversation, discourse and document analysis. London: Sage

33. Sinkkonen, I., Kuoppala, H., and Parkkinen, J. (2002), Käytettävyyden psykologia. Edita Oyj, Helsinki.

34. S. H .Blakstad, G. K. Hansen and W. Knudsen, "Methods and tools for evaluation of usability in buildings",Usability of Workplaces 2, CIB and EuroFM. CIB reports 316.Rotterdam,2008.

35. S.Nenonen and H. Rasila , "Customer Journey - a method to investigate user experience", International Council for Research and Innovation in Building and Construction (CIB) reports 316. 2008

36. T .Kazanasmaz, “ Design Efficiency in Hospital Architecture", Proceedings of First International CIB Endorsed METU Graduate Conference, Ankara,Turkey, 17-18 March 2006, pp.231242,2006.

37. T. J. M. v. d. Voordt, "Quality of design and usability: a vetruvian twin." Ambiente Construído, Porto Alegre 9,(2),pp. 17-29,2009

38. T. Uehira and C.Kay,"Using design thinking to improve patient experiences in Japanese hospitals: a case study", Journal of Business Strategy, Vol. 30 Iss: $2 / 3$, pp. $6-12,2009$.

39. Yin, R. K. (1994). Case study research: Design and methods (2nd ed.). Thousand Oaks, CA: Sage.

40. Kamarulzaman, Y., \& Author, C. (2010). Attracting Shoppers to Shopping Malls : The Malaysian Perspective, 185-199.

41. Sapie, N. M., Hussain, M. Y., Ishak, S., Awang, A. H., \& Lyndon, N. (2014). Motif dan daya tarikan pusat membeli-belah dalam kalangan pengunjung metropolitan Kuala Lumpur, Malaysia Patron motives and perspectives of shopping malls , attraction in Metropolitan Kuala Lumpur, 1(1), 70 77.

42. Zahari, A. R., Esa, E., Nasional, U. T., Haji, S., \& Shah, A. (2012). TIMBJ, 2(2), 47-60. 